\title{
ORGANY I FUNKCJE REGULACYJNE ADMINISTRACJI W RELACJI POMIĘDZY UNIĄ EUROPEJSKĄ I PORZĄDKAMI KRAJOWYMI
}

DOI: http://dx.doi.org/10.12775/TSP-W.2013.015

Członkostwo Polski w Unii Europejskiej wywiera bardzo istotny wpływ na system instytucjonalny oraz szeroko rozumiane funkcjonowanie krajowej administracji publicznej, w tym również jej współdziałanie z organami administracyjnymi państw członkowskich Unii Europejskiej, jak też samymi organami Unii. Celem opracowania jest przedstawienie pozycji ustrojowej organów regulacyjnych oraz istoty funkcji regulacyjnych administracji publicznej w gospodarce z perspektywy prawa unijnego i polskiego porządku prawnego. Nie będą natomiast przedmiotem analizy zagadnienia materialnoprawne, a w szczególności konkretne kompetencje organów regulacyjnych i instrumenty służące realizacji funkcji regulacyjnej, jak również postępowanie przed organami regulacyjnymi, a więc szeroko rozumiane kwestie procesowe.

W warunkach polskich problem organów i funkcji regulacyjnych wydaje się szczególnie istotny i interesujący z uwagi fakt, iż są to w polskiej praktyce, jak i nauce prawa administracyjnego, stosunkowo nowe i nie do końca opracowane zagadnienia. Ich występowanie w aparacie administracyjnym państwa wiąże się bowiem z transformacją ustrojową zapoczątkowaną na przełomie lat osiemdziesiątych i dziewięćdziesiątych dwudziestego wieku, jak też przystąpieniem Polski do Unii Europejskiej, formalnie w 2004 r. I niezależnie od stopnia zaawansowania badań im poświęconym, stanowią one współcześnie istotny i niezbędny element polskiej administracji publicznej, tak w ujęciu ustrojowym, jak i funkcjonalnym. 
Koniecznym wydaje się więc w pierwszej kolejności wskazanie na przyjęte dla potrzeb tego opracowania pojęcie organu regulacyjnego i istoty funkcji regulacyjnej, a więc podmiotów administracji publicznej koncentrujących swoją aktywność na specyficznej funkcji regulatora rynków infrastrukturalnych. Pojęcia te pozostają ze sobą $\mathrm{w}$ nierozerwalnym związku, bowiem ustalenie pojęcia organu regulacyjnego nie jest obecnie możliwe bez pojęcia regulacji jako specyficznej funkcji państwa, która w odniesieniu do organu regulacyjnego stanowi kategorię pierwotną.

Podejmując więc próbę określenia pozycji prawnej organu regulacyjnego, musimy posłużyć się nietypowym dla klasycznej teorii organu administracji publicznej kryterium ich klasyfikacji. Zamiast bowiem odnoszenia się do pozycji ustrojowej, typu podporządkowania, czy właściwości rzeczowej, przyjmiemy kryterium specyfiki wykorzystywanych instrumentów prawnych, co w przedmiotowym przypadku oznacza wyposażenie organu w specyficzne uprawnienia ingerencji w rynek o charakterze regulacyjnym. Nie umniejszając znaczenia innych elementów konstrukcyjnych organu regulacyjnego, które będą miały znaczenie pochodne i uzupełniające, ta cecha wydaje się kluczowa, zwłaszcza w zakresie ustrojowego podejścia do pojęcia organu regulacyjnego. Takie ujęcie pozwoli na wyodrębnienie organu regulacyjnego w wąskim znaczeniu, zgodnie z którym będzie to organ administracji publicznej posiadający zadania i odpowiadające im kompetencje typowe dla funkcji regulacyjnej, a jednocześnie powołany przez ustawodawcę głównie w celu jej realizacji. Przyjęcie bowiem znaczenia szerokiego oznaczałoby uznanie za organ regulacyjny każdego organu administracji publicznej, który w jakimkolwiek stopniu wykonuje funkcje regulacyjne. Dzięki przyjęciu wąskiego znaczenia organu regulacyjnego przedmiotem rozważań nie obejmujemy organów, których zasadnicze zadania i odpowiadające im kompetencje nie służą realizacji funkcji regulacyjnej ${ }^{1}$.

W warunkach polskich typowym przykładem podmiotów utworzonych do wykonywania bardzo wielu istotnych funkcji są organy jednostek samorządu terytorialnego. Jedną z funkcji powierzonych do realizacji samorządowi terytorialnemu jest funkcja regulacyjna występująca $\mathrm{w}$ zakresie oddziaływania podstawowej jednostki samorządu terytorialnego w sferze gospodarczej, choć biorąc pod uwagę całokształt zadań i kompetencji polskich organów samorządowych, ma ona znaczenie marginalne. Reprezentatywnym przykładem w tym zakresie

${ }^{1}$ K. Jaroszyński, M. Wierzbowski, Organy regulacyjne, [w:] System prawa administracyjnego. Podmioty administrujące, t. 6, pod red. R. Hausera, Z. Niewiadomskiego, A. Wróbla, C.H. Beck, Instytut Nauk Prawnych PAN, Warszawa 2011, s. 306-307. 
są przepisy ustawy z dnia 7 czerwca 2001 r. o zbiorowym zaopatrzeniu w wodę i zbiorowym odprowadzaniu ścieków ${ }^{2}$. $Z$ jednej strony zgodnie $z$ art. 16 powołanej ustawy wyposażono gminę $w$ typowe kompetencje reglamentacyjne, stanowiąc, że na prowadzenie zbiorowego zaopatrzenia w wodę lub zbiorowego odprowadzania ścieków jest wymagane uzyskanie zezwolenia wydawanego przez wójta (burmistrza, prezydenta miasta) w drodze decyzji, a więc kompetencje do wydawania zezwoleń na prowadzenie działalności gospodarczej. Z drugiej jednak strony ta sama ustawa stanowi o zatwierdzaniu przez organy samorządu gminnego taryf, rozumianych jako zestawienie ogłoszonych publicznie cen i stawek opłat za zbiorowe zaopatrzenie $\mathrm{w}$ wodę i zbiorowe odprowadzanie ścieków oraz warunki ich stosowania, co stanowi typowy przykład regulacji. W myśl bowiem art. 24 ustawy o zbiorowym zaopatrzeniu w wodę i zbiorowym odprowadzaniu ścieków taryfy, z wyjątkiem taryf zmienionych w związku ze zmianą stawki podatku od towarów i usług, podlegają na wniosek przedsiębiorstwa wodno-kanalizacyjnego oraz po weryfikacji wniosku przez wójta (burmistrza, prezydenta miasta) zatwierdzeniu w drodze uchwały rady gminy. Mimo tego organy jednostek samorządu terytorialnego, a w szczególności organy gminy nie są kwalifikowane jako organy regulacyjne w ścisłym, wąskim znaczeniu.

Warto także podkreślić, że w niektórych przypadkach wyróżnienie organu regulacyjnego w oparciu o zaproponowaną cechę czyli jego powołanie w głównym celu realizacji funkcji regulacyjnej, ze względu na jej nieprecyzyjność będzie stosunkowo trudne. Chodzi bowiem o organy, które wykonują kilka powierzonych im do realizacji funkcji, a przypisane im zadania nie dotyczą wyłącznie funkcji regulacyjnej, a przy tym dysproporcja tych funkcji pozostałych do funkcji regulacyjnej nie będzie tak oczywista, jak w przypadku organów samorządu terytorialnego. Typowym przykładem takiej sytuacji jest Prezes Urzędu Transportu Kolejowego, działający na podstawie ustawy z dnia 28 marca 2003 r. o transporcie kolejowym ${ }^{3}$. Zgodnie z art. 10 ust. 1 powołanej ustawy Prezes Urzędu Transportu Kolejowego jest centralnym organem administracji rządowej będącym krajową władzą bezpieczeństwa i krajowym regulatorem transportu kolejowego w rozumieniu przepisów Unii Europejskiej z zakresu bezpieczeństwa i regulacji transportu kolejowego, właściwym w sprawach regulacji transportu kolejowego, licencjonowania transportu kolejowego, nadzoru technicznego nad eksploatacją i utrzymaniem linii kolejowych oraz pojazdów kolejowych, bezpieczeństwa

\footnotetext{
T. j. Dz.U. z 2006 r. Nr 123, poz. 858 ze zm.

3 T. j. Dz.U. z 2007 r. Nr 16, poz. 94 ze zm.
} 
ruchu kolejowego, nadzoru nad przestrzeganiem praw pasażerów w transporcie kolejowym, licencji i świadectw maszynistów.

Już nawet pobieżna analiza właściwości tego organu pozwala stwierdzić, że organ ten formalnie zakwalifikowany przez ustawodawcę do organów regulacyjnych posiada dodatkowe ,pozaregulacyjne” zadania. Dlatego dla jednoznacznego wyróżnienia kategorii organów regulacyjnych proponuje się obok kryterium ilościowego polegającego, jak już wspomniano, na porównaniu ilościowym kompetencji regulacyjnych i pozostałych, dodatkowego kryterium jakościowego, sprowadzającego się do oceny instrumentu regulacyjnego z punktu widzenia intensywności oddziaływania na rynek. Przyjęcie takiego założenia pozwala na stwierdzenie, że dany organ administracji publicznej może być zakwalifikowany do grupy organów regulacyjnych, jeżeli posiada rozbudowane możliwości wpływu na rynek dzięki kompetencjom regulacyjnym, które nie są marginalizowane w relacji do pozostałych jego uprawnień. Taki punkt widzenia usuwa wątpliwości kwalifikacyjne w przypadku Prezesa Urzędu Transportu Kolejowego, bowiem jego - występujące poza sferą regulacyjną - obowiązki pozostają w ścisłym związku z kwestią dostępu do rynku przedsiębiorców, dopuszczalności i warunków działalności gospodarczej, a tym samym pozwalają intensywnie oddziaływać na rynek w tym sektorze infrastrukturalnym ${ }^{4}$.

Polski ustawodawca nie posługuje się jednak jednolitym pojęciem organu regulacyjnego, co powoduje, że jest to raczej pojęcie doktrynalne i nie zawsze występuje w języku prawnym. Dzieje się tak na przykład w przepisach ustawy z dnia 10 kwietnia 1997 r. Prawo energetyczne ${ }^{5}$, która Prezesa Urzędu Regulacji Energetyki nazywa organem do spraw regulacji gospodarki paliwami i energią. Podobnie, zgodnie z przepisami ustawy z dnia 16 lipca 2004 r. Prawo telekomunikacyjne ${ }^{6}$ Prezes Urzędu Komunikacji Elektronicznej jest organem regulacyjnym $w$ dziedzinie rynku usług telekomunikacyjnych i pocztowych. $Z$ kolei przepisy ustawy z dnia 28 marca 2003 r. o transporcie kolejowym ${ }^{7}$ określają Prezesa Urzędu Transportu Kolejowego krajowym regulatorem transportu kolejowego w rozumieniu przepisów Unii Europejskiej z zakresu bezpieczeństwa i regulacji transportu kolejowego. Natomiast nie posługuje się tym pojęciem ustawodawca w przypadku Komisji Nadzoru Finansowego w ustawie z dnia 21 lipca 2006 r. o nadzorze nad rynkiem finansowym ${ }^{8}$, a także ustawa z dnia 16 lutego $2007 \mathrm{r}$.

\footnotetext{
${ }^{4}$ K. Jaroszyński, M. Wierzbowski, op. cit., s. 308.

5 T. j. Dz.U. z 2012 r., poz. 1059 ze zm.

${ }^{6}$ Dz.U. Nr 171, poz. 1800 ze zm.

7 T. j. Dz.U. z 2007 r. Nr 16, poz. 94 ze zm.

8 T. j. Dz.U. z 2012 r., poz. 1149 ze zm.
} 
o ochronie konkurencji i konsumentów ${ }^{9}$ przypadku Prezesa Urzędu Ochrony Konkurencji i Konsumentów.

Jak podkreślono wcześniej, zaliczenie określonych podmiotów administracji publicznej do grupy organów regulacyjnych wiąże się z realizowaniem przez te organy funkcji regulacyjnych. Również i to pojęcie nie jest typowe dla klasycznej nauki prawa administracyjnego i budzi wiele kontrowersji, choć coraz częściej, zwłaszcza w opracowaniach dotyczących administracji gospodarczej funkcja regulacyjna jest prezentowana obok takich typowych funkcji jak np. funkcja reglamentacyjna, policyjna, nadzorcza, czy kierownicza. Przy czym funkcja administracji będzie tu rozumiana jako ogólny kierunek działania organu, wokół którego ogniskują się specyficzne zadania, cele kompetencje, formy działania i zasady, ujęte w szeregu regulacji prawnych, które rozpatrywane łącznie pozwalają na stwierdzenie określonej funkcji administracji ${ }^{10}$. Istotę określonej funkcji administracji sprowadzić można jednak do trzech zasadniczych elementów, jakimi są przedmiot, sposób (metoda) oddziaływania oraz cel jego realizacji, które w przypadku funkcji regulacyjnej pozwalają na bezpośrednie oddziaływanie na zachowania rynkowe przedsiębiorców.

Po pierwsze - dotyczy ona zachowań i aktywności przedsiębiorców, które w normalnych warunkach mieszczą się w ramach gwarantowanej swobody działalności gospodarczej i co do zasady podlegają regułom ekonomii a nie prawa. Przede wszystkim chodzi tu o władczą ingerencję w decyzje przedsiębiorców wynikające ze swobody umów. Oznacza to de facto horyzontalne oddziaływanie funkcji regulacyjnej na rynek, a więc oddziaływania w sferze stosunków między przedsiębiorcami oraz przedsiębiorcami i konsumentami.

Po drugie - metoda regulacyjna polega na oddziaływaniu organów administracji na podmioty gospodarcze na zasadzie uznania administracyjnego przysługującego tym organom. W literaturze przedmiotu podkreśla się istnienie uznaniowości regulacyjnej, wynikającej ze swobody oceny przez organ regulacyjny stanu faktycznego, jak też interpretacji pojęć niedookreślonych w kontekście celów regulacji. Nie jest to więc klasycznie pojmowane uznanie administracyjne, a raczej należałoby element ten określić jako uprawnienia o charakterze dyskrecjonalnym odnoszące się do różnych etapów stosowania prawa, w tym również wyboru konsekwencji prawnych działania organu regulacyjnego polegających wyborze odpowiednich instrumentów regulacyjnych.

\footnotetext{
${ }^{9}$ Dz.U. Nr 50, poz. 331 ze zm.

${ }^{10}$ K. Jaroszyński, M. Wierzbowski, op. cit., s. 314-315.
} 
Po trzecie - działanie administracji jest zdeterminowane celami regulacji, sprowadzającymi się zasadniczo do polityki państwa zakładającej ingerencję w rynki, w których nie funkcjonują typowe mechanizmy rynkowe. Tymi celami są więc konkurencja na rynku i interes konsumentów. A ujmując to szerzej można stwierdzić, że celem regulacji jest służenie interesowi publicznemu, gdyż występuje ona w sferze użyteczności publicznej (telekomunikacja, energetyka, transport kolejowy) ${ }^{11}$.

Podkreślenia wymaga również fakt, iż regulacja i funkcja regulacyjna są przede wszystkim pojęciami prawniczymi, choć w polskim porządku prawnym odnajdujemy przepisy prawa, które pozwalają zaleczyć je również do pojęć prawnych. Najbardziej reprezentatywnym przykładem w tym zakresie są przepisy ustawy z dnia 10 kwietnia 1997 r. Prawo energetyczne, które w art. 3 pkt 15 definiują regulację jako stosowanie określonych ustawą środków prawnych, włącznie z koncesjonowaniem, służących do zapewnienia bezpieczeństwa energetycznego, prawidłowej gospodarki paliwami i energią oraz ochrony interesów odbiorców. Generalnie ta legalna definicja regulacji potwierdza przyjęte założenia teoretyczne, choć należy zwrócić uwagę na fakt, iż ma ona szerszy charakter, bowiem obejmuje swoim zakresem obok typowej funkcji regulacyjnej, również funkcję reglamentacyjną (koncesjonowanie). Zjawisko to należy ocenić negatywnie, bowiem funkcja reglamentacyjna ma inny charakter i służy innym celom, a ponadto współczesna polska regulacja prawna nie wiąże reglamentacji z uznaniem administracyjnym, co jeszcze do niedawna wskazywała doktryna prawa administracyjnego w ramach klasycznego ujęcia reglamentacji.

Powstanie $\mathrm{w}$ warunkach polskich organów regulacyjnych było wynikiem przyjęcia prawodawstwa unijnego, zakładającego funkcjonowanie niezależnych organów mających na celu nadzorowanie i regulowanie gospodarki w najistotniejszych dla każdego państwa członkowskiego obszarach, tzw. sektorach infrastrukturalnych. Jako przykłady takich regulacji unijnych można wskazać:

- dyrektywę 2003/54/WE Parlamentu Europejskiego i Rady z 26 czerwca 2003 r. dotyczącą wspólnych zasad rynku wewnętrznego energii elektrycznej i uchylającą dyrektywę 96/92/WE ${ }^{12}$, która w art. 23 ust. 1 zobowiązuje państwa członkowskie do określenia jednej lub więcej właściwych jednostek, którym powierzają funkcje organów regulacyjnych, całkowicie niezależnych od interesów przemysłu energetycznego;

${ }^{11}$ K. Jaroszyński, M. Wierzbowski, op. cit., s. 316-317.

12 Dz.Urz. UE L Nr 76, s. 37. 
- dyrektywę 2002/21/WE Parlamentu Europejskiego i Rady z 7 marca 2002r. w sprawie wspólnych ram regulacyjnych sieci i usług łączności elektronicznej ${ }^{13}$, która $w$ art. 3 poświęconym właśnie krajowym organom regulacyjnym w ust. 1 zobowiązuje państwa do zapewnienia, by zadania przydzielone krajowym organom regulacyjnym były realizowane przez uprawnione organy wyposażone w prawnie zagwarantowaną niezależność od wszelkich organizacji udostępniających sieci, urządzenia lub usługi łączności elektronicznej;

- dyrektywę 2001/14/WE Parlamentu Europejskiego i Rady z 26 lutego 2001 r. w sprawie alokacji zdolności przepustowej infrastruktury kolejowej i pobierania opłat za użytkowanie infrastruktury kolejowej oraz przyznawanie świadectw bezpieczeństwa 14, która w art. 30 ust. 1 poświęconym organowi kontroli, przesądza o powołaniu przez państwa członkowskie organu, który będzie niezależny w swojej organizacji, decyzjach finansowych, strukturach prawnych i podejmowaniu decyzji od któregokolwiek zarządcy infrastruktury, organu pobierającego opłaty, organu alokującego lub wnioskodawcy;

- dyrektywę 97/67/WE Parlamentu Europejskiego i Rady z 15 grudnia 1997 r. w sprawie wspólnych zasad rozwoju rynku wewnętrznego usług pocztowych Wspólnoty oraz poprawy jakości usług, która w art. 22 określa, że każde państwo członkowskie wyznaczy dla sektora pocztowego krajowy organ regulacyjny lub krajowe organy regulacyjne, które będą odrębne prawnie i niezależne funkcjonalnie od operatorów pocztowych;

- rozporządzenie Rady (WE) Nr 1/2003 z 16 grudnia 2002 r. w sprawie wprowadzenia $w$ życie reguł konkurencji ustanowionych w art. 81 i 82 Traktatu, które w art. 35, poświęconym wyznaczaniu organów ochrony konkurencji państw członkowskich w ust. 1 stanowi, że państwa członkowskie wyznaczą organ lub organy ochrony konkurencji odpowiedzialne za stosowanie art. 81 i 82 Traktatu $^{15}$ w sposób, który zapewni skuteczne wykonanie przepisów rozporządzenia.

Brak związania określonym modelem organizacyjnym przy implementacji wskazanych wcześniej przepisów determinujących utworzenie organów regulacyjnych, spowodowały, że polski ustawodawcza nie przyjął jednolitego modelu

\footnotetext{
${ }^{13}$ Dz.Urz. UE L Nr 108, s. 33.

14 Dz.Urz. UE L Nr 75, s. 29.

15 Dz.Urz. UE L Nr 1, s. 1.
} 
administracji wykonującej funkcje regulacyjne. Obecnie na gruncie prawa polskiego można wyróżnić trzy rodzaje organów regulacyjnych.

Grupa pierwsza, najbardziej typowa, to organy regulacyjne, których właściwość odnosi się do poszczególnych rynków regulowanych, do których należą rynek energetyczny, rynek telekomunikacyjny i rynek kolejowy. Funkcje regulacyjne wykonują tu:

1. Prezes Urzędu Regulacji Energetyki na podstawie przepisów ustawy z dnia 10 kwietnia 1997 r. Prawo energetyczne,

2. Prezes Urzędu Komunikacji Elektronicznej w oparciu o przepisy ustawy z dnia 16 lipca 2004 r. Prawo telekomunikacyjne,

3. Prezes Urzędu Transportu Kolejowego zgodnie z ustawą 28 marca 2003 r. o transporcie kolejowym.

Zgodnie z art. 21 Prawa energetycznego zadania z zakresu spraw regulacji gospodarki paliwami i energią oraz promowania konkurencji realizuje Prezes Urzędu Regulacji Energetyki (Prezes URE), będący centralnym organem administracji rządowej. Prezesa URE powołuje Prezes Rady Ministrów, spośród osób wyłonionych w drodze otwartego i konkurencyjnego naboru, na wniosek ministra właściwego do spraw gospodarki. Prezes Rady Ministrów odwołuje Prezesa URE. W myśl art. 23 Prawa energetycznego Prezes URE reguluje działalność przedsiębiorstw energetycznych zgodnie z ustawą i polityką energetyczną państwa, zmierzając do równoważenia interesów przedsiębiorstw energetycznych i odbiorców paliw i energii.

Według art. 190 ust. 1 Prawa telekomunikacyjnego Prezes Urzędu Komunikacji Elektronicznej (Prezes UKE) jest organem regulacyjnym w dziedzinie rynku usług telekomunikacyjnych i pocztowych. Prezes UKE jest centralnym organem administracji rządowej. Prezesa UKE powołuje i odwołuje Sejm za zgodą Senatu na wniosek Prezesa Rady Ministrów. Kadencja Prezesa UKE trwa 5 lat. Po upływie kadencji Prezes UKE pełni swoją funkcję do czasu powołania następcy. Prezes UKE może być odwołany przed upływem kadencji, na którą został powołany, wyłącznie w przypadkach ustawowo określonych. Do zakresu działania Prezesa UKE należy w szczególności wykonywanie, przewidzianych ustawą i przepisami wydanymi na jej podstawie, zadań z zakresu regulacji i kontroli rynków usług telekomunikacyjnych, gospodarki w zakresie zasobów częstotliwości, zasobów orbitalnych i zasobów numeracji oraz kontroli spełniania wymagań dotyczących kompatybilności elektromagnetycznej oraz wykonywanie zadań z zakresu regulacji działalności pocztowej.

Natomiast według art. 10 ustawy o transporcie kolejowym centralnym organem administracji rządowej będącym krajową władzą bezpieczeństwa i krajowym 
regulatorem transportu kolejowego w rozumieniu przepisów Unii Europejskiej z zakresu bezpieczeństwa i regulacji transportu kolejowego, właściwym w sprawach wcześniej już cytowanych jest Prezes Urzędu Transportu Kolejowego (Prezes UTK). Prezes Urząd Transportu Kolejowego jest powoływany przez Prezesa Rady Ministrów, spośród osób wyłonionych w drodze otwartego i konkurencyjnego naboru, na wniosek ministra właściwego do spraw transportu. Prezes Rady Ministrów odwołuje Prezesa UTK. Nadzór nad Prezesem UTK sprawuje minister właściwy do spraw transportu.

Do drugiej grupy należy zaliczyć organ regulacyjny, związany z rynkami określonymi rodzajowo, a nie jak w pierwszej grupie konkretnie, tj. rynkami finansowymi. Organem tym jest Komisja Nadzoru Finansowego działająca na podstawie ustawy z dnia 21 lipca 2006 r. o nadzorze nad rynkiem finansowym. Zgodnie z art. 3 powołanej ustawy tworzy się Komisję Nadzoru Finansowego, która jest organem właściwym w sprawach nadzoru nad rynkiem finansowym. Zaś nadzór nad jej działalnością sprawuje Prezes Rady Ministrów. Do zadań Komisji Nadzoru Finansowego należy w szczególności: sprawowanie nadzoru nad rynkiem finansowym, podejmowanie działań służących prawidłowemu funkcjonowaniu rynku finansowego, jak również podejmowanie działań ma jących na celu rozwój rynku finansowego i jego konkurencyjności. W skład Komisji wchodzą Przewodniczący, dwóch Zastępców Przewodniczącego i czterech członków. Członkami Komisji są minister właściwy do spraw instytucji finansowych albo jego przedstawiciel, minister właściwy do spraw zabezpieczenia społecznego albo jego przedstawiciel, Prezes Narodowego Banku Polskiego albo delegowany przez niego Wiceprezes Narodowego Banku Polskiego, przedstawiciel Prezydenta Rzeczypospolitej Polskiej. Przewodniczącego Komisji powołuje Prezes Rady Ministrów na pięcioletnią kadencję.

Grupę trzecią tworzy Prezes Urzędu Ochrony Konkurencji i Konsumentów działający na podstawie ustawy z dnia 16 lutego 2007 r. o ochronie konkurencji i konsumentów. Jego właściwość regulacyjna obejmuje praktycznie każdy rynek i każdą działalność gospodarczą. Na podstawie art. 29 powołanej ustawy Prezes Urzędu Ochrony Konkurencji i Konsumentów (Prezes UOKiK) jest centralnym organem administracji rządowej właściwym w sprawach ochrony konkurencji i konsumentów. Prezes Rady Ministrów powołuje Prezesa UOKiK spośród osób wyłonionych w drodze otwartego i konkurencyjnego naboru ${ }^{16}$.

${ }^{16}$ K. Jaroszyński, M. Wierzbowski, op. cit., s. 312-313. 
Na podstawie analizy przepisów krajowego porządku prawnego można wyróżnić dwie kolejne, obok przyjętych wcześniej do zdefiniowania organu regulacyjnego, cechy charakteryzujące polski organy regulacyjne.

Po pierwsze - organy regulacyjne należą do grupy centralnych organów administracji rządowej, choć pewnych trudności kwalifikacyjnych ze względu na swój skład nastręcza Komisja Nadzoru Finansowego. Takie ich usytuowanie jest wynikiem konieczności objęcia ich działalnością wszystkich rynków, które wymagają jednolitego działania w skali całego kraju. Zatem zakresem ich właściwości w sferze regulacji nie są objęte rynki o charakterze lokalnym, przypisane najczęściej organom jednostek samorządu terytorialnego, jak we wspomnianym już przykładzie zbiorowego zaopatrzenia w wodę i zbiorowego odprowadzania ścieków. Przy akceptacji centralnego charakteru organów regulacyjnych, wątpliwym choć dopuszczalnym rozwiązaniem było włączenie organów regulacyjnych do administracji rządowej, bowiem implikuje to istotne ograniczenie ich niezależności.

Stąd też po drugie - cechą polskich organów regulacyjnych jest ich swoista niezależność. Wyposażenie organu regulacyjnego w niezależność ma na celu ograniczenie wpływu na ich działalność zarówno przedsiębiorców, co wynika również z przepisów unijnych determinujących powstanie organów regulacyjnych, jak również wpływów o charakterze politycznym. W tym drugim przypadku chodzi przede wszystkim o przepisy regulujące procedury obsady personalnej podstawowych stanowisk w organach regulacyjnych, np. powołanie ich prezesów w drodze otwartego i konkurencyjnego konkursu, jak też o ich usytuowanie w aparacie administracyjnym państwa przez poddanie ich wyłącznie nadzorowi organów naczelnych administracji państwowej. Jak podkreśla się jednak w literaturze niezależność od wpływów politycznych, zarówno w sferze personalnej, jak i organizacyjnej ma charakter względny. Najdalej idącą niezależność organów regulacyjnych należy dostrzec w ich sferze decyzyjnej bowiem żaden z naczelnych organów administracji państwowej sprawujący nadzór nad działalnością organów regulacyjnych nie ma bezpośredniego wpływu na ich decyzje w sferze merytorycznej ${ }^{17}$. Merytoryczna kontrola rozstrzygnięć należy do niezawisłych sądów. W literaturze podkreśla się jednak, że współczesne tendencje w prawie Unii Europejskiej doprowadzą przez jego implementację do porządków krajowych do zwiększenia stopnia niezależności organów regulacyjnych,

${ }_{17}$ M. Wierzbowski, J. Jagielski, Organy regulacyjne - wybrane problemy, [w:] Współczesne zagadnienia prawa i procedury administracyjnej. księga jubileuszowa dedykowana prof. $z w . d r$. hab. Jackowi M. Langowi, pod red. M. Wierzbowskiego, J. Jagielskiego, A. Wiktorowskiej, E. Stefańskiej, Wolters Kluwer, Warszawa 2009, s. 354-358. 
co jednoznacznie wskazuje na wzrost roli prawa unijnego w zakresie ich funkcjonowania i ograniczenie autonomii prawa krajowego. Przykładem takich rozwiązań może być regulacja wynikająca z art. 35 dyrektywy Parlamentu Europejskiego i Rady 2009/72/WE z 13 lipca 2009 r. dotyczącej wspólnych zasad rynku wewnętrznego energii elektrycznej i uchylającej dyrektywę 2003/54/WE ${ }^{18}$. Dotyczy on właśnie wyznaczania i niezależności organów regulacyjnych i stanowi, że państwa członkowskie gwarantują niezależność organu regulacyjnego i zapewniają, aby wykonywał on swoje uprawnienia w sposób bezstronny i przejrzysty. W tym celu państwa członkowskie zapewniają, aby przy wykonywaniu zadań regulacyjnych powierzonych mu na mocy niniejszej dyrektywy i aktów powiązanych organ regulacyjny był prawnie odrębny i funkcjonalnie niezależny od jakiegokolwiek innego podmiotu publicznego lub prywatnego, zapewniał, aby jego pracownicy oraz osoby odpowiedzialne za zarządzanie nim działali niezależnie od wszelkich interesów rynkowych oraz przy wykonywaniu swoich zadań regulacyjnych nie zwracali się o bezpośrednie polecenia ani nie wykonywali bezpośrednich poleceń któregokolwiek rządu lub innego podmiotu publicznego lub prywatnego. W celu ochrony niezależności organu regulacyjnego państwa członkowskie zapewniają w szczególności, aby organ regulacyjny mógł podejmować niezależne decyzje, niezależnie od jakichkolwiek podmiotów politycznych, oraz posiadał co roku odrębne środki budżetowe i niezależność w wykonywaniu przyznanego budżetu oraz odpowiednie zasoby kadrowe i finansowe do wykonywania swoich obowiązków oraz aby członkowie zarządu organu regulacyjnego lub, w przypadku braku zarządu, ścisłego kierownictwa organu regulacyjnego byli powoływani na ustaloną kadencję od pięciu do siedmiu lat, z możliwością jednokrotnego odnowienia.

Tak więc prawo europejskie w istotny sposób wpłynęło na powstanie i w sposób coraz bardziej intensywny wpływa na pozycję ustrojową organów regulacyjnych państw członkowskich. Tendencja ta znajduje swoje uzasadnienie w koncepcji wykonywania prawa europejskiego przez organy państw członkowskich, które w tym zakresie muszą być traktowane nie tylko jako podmioty krajowego porządku prawnego, a również jako administracja europejska odpowiedzialna za wykonanie przepisów prawodawstwa europejskiego.

Podkreślić także należy, że organy regulacyjne mają być niezależne, jednak niezależność ta ma je chronić przed przedsiębiorcami wobec których mogą być podejmowane działania mieszczące się w funkcji regulacyjnej i przed wpływami politycznymi ze strony podmiotów krajowych. Nie dotyczy to jednak wpływów

18 Dz. Urz. UE L 211, s. 55. 
instytucji europejskich, które w równie istotny sposób, jak w przypadku tworzenia, wpływają na zasady funkcjonowania organów regulacyjnych. W szczególności chodzi o przepisy, które zobowiązują organy regulacyjne do współdziałania z dwoma rodzajami podmiotów, organami regulacyjnymi poszczególnych państw członkowskich, jak też organami europejskimi w ścisłym tego słowa znaczeniu.

W pierwszym przypadku obowiązek współpracy organów regulacyjnych między sobą wprowadzony został w przepisach licznych dyrektyw, do których należą w szczególności:

- art. 7 dyrektywy 2002/21/WE Parlamentu Europejskiego i Rady z 7 marca 2002 r. w sprawie wspólnych ram regulacyjnych sieci i usług łączności elektronicznej, zgodnie z którym krajowe organy regulacyjne będą przyczyniać się do rozwoju rynku wewnętrznego poprzez przejrzystą wzajemną współpracę oraz współpracę z Komisją celem zapewnienia jednolitego wdrażania we wszystkich Państwach Członkowskich postanowień niniejszej dyrektywy i dyrektyw szczegółowych. W tym celu będą one w szczególności zmierzać do osiągnięcia porozumienia co do rodzajów instrumentów i środków naprawczych najlepiej nadających się do zastosowania w określonych sytuacjach rynkowych;

- art. 23 ust. 12 dyrektywy 2003/54/WE Parlamentu Europejskiego i Rady z 26 czerwca 2003 r. dotyczącą wspólnych zasad rynku wewnętrznego energii elektrycznej, w myśl którego krajowe organy regulacyjne przyczyniają się do rozwoju rynku wewnętrznego i jednakowych warunków działania poprzez wzajemną współpracę oraz współpracę z Komisją w przejrzysty sposób;

- art. 31 dyrektywy 2001/14/WE Parlamentu Europejskiego i Rady z 26 lutego $2001 \mathrm{r}$. w sprawie alokacji zdolności przepustowej infrastruktury kolejowej i pobierania opłat za użytkowanie infrastruktury kolejowej oraz przyznawanie świadectw bezpieczeństwa, według którego krajowe organy kontrolne będą wymieniać informacje o swojej pracy oraz zasadach i praktyce podejmowania decyzji w celu koordynowania zasad podejmowania przez nich decyzji na obszarze całej Wspólnoty. Komisja będzie wspierać je w wykonywaniu tego zadania.

Współpraca między krajowymi organami regulacyjnymi przewidziana przez powołane przepisy w ramach Unii Europejskiej wydaje się oczywista i nie budzi wątpliwości. Należy jednak znowu zauważyć, że tendencja w zakresie zacieśniania współpracy przez rozszerzenie zakresu prawodawstwa europejskiego ogranicza krajowe porządki prawne. Jako typowy przykład należy wskazać zinstytucjonalizowanie współpracy organów regulacyjnych poszczególnych państw 
członkowskich w postaci tworzonych przez Komisję w drodze decyzji sieci (grup) organów ${ }^{19}$. Jako przykład mogą tu posłużyć:

- Europejska Grupa Organów Regulacyjnych dla Sieci i Usług Łączności Elektronicznej, utworzona decyzją 2002/627/WE Komisji z 29 lipca 2002 r. o utworzeniu Europejskiej Grupy Organów Regulacyjnych dla Sieci i Usług Łączności Elektronicznejej;

- Europejska Grupa Organów Regulacyjnych dla Energii Elektrycznej i Gazu Ziemnego, utworzona decyzją 2003/796/WE Komisji z 11 listopada 2003 r. o utworzeniu Europejskiej Grupy Organów Regulacyjnych dla Energii Elektrycznej i Gazu Ziemnego ${ }^{21}$.

Wskazane wcześniej przepisy dyrektyw mogą posłużyć jednocześnie za przykład obowiązku współdziałania organów regulacyjnych z właściwymi organami europejskimi, a w szczególności z Komisją. Również i w tym przypadku poza przepisami zobowiązującymi do współpracy z Komisją, która nie ma charakteru wiążącego, a tym samym nie kształtuje sytuacji prawnej rynku, można dostrzec liczne przypadki współpracy o wiążącym charakterze, a więc wpływającej w sposób bezpośredni na treść rozstrzygnięć organów regulacyjnych. Przykładem może być prowadzone przez Prezesa Urzędu Komunikacji Elektronicznej postępowanie konsolidacyjne. Zgodnie bowiem z art. 18 Prawa telekomunikacyjnego, jeżeli rozstrzygnięcia Prezesa UKE dotyczące między innymi określenia rynku właściwego, a także jego analizy i wyznaczenia przedsiębiorcy telekomunikacyjnego o znaczącej pozycji rynkowej lub przedsiębiorców telekomunikacyjnych zajmujących kolektywną pozycję znaczącą, lub uchylenia decyzji w tej sprawie, a także nałożenia, zniesienia, utrzymania lub zmiany obowiązków regulacyjnych w stosunku do przedsiębiorcy telekomunikacyjnego o znaczącej pozycji lub nieposiadającego takiej pozycji, mogą mieć wpływ na stosunki handlowe między państwami członkowskimi, Prezes UKE rozpoczyna postępowanie konsolidacyjne, przesyłając Komisji Europejskiej i organom regulacyjnym innych państw członkowskich projekty rozstrzygnięć wraz z ich uzasadnieniem. Jeżeli Komisja Europejska i organy regulacyjne innych państw członkowskich wyrażą stanowisko do projektu rozstrzygnięcia, Prezes UKE niezwłocznie uwzględnia to stanowisko w możliwie najszerszym zakresie. Jeżeli w zakresie ustalenia znaczącej pozycji rynkowej oraz w zakresie zamiaru zdefiniowania rynku właściwego innego niż rynki określone w zaleceniu Komisji Europejskiej w sprawie właściwych rynków

19 J. Supernat, Koncepcja sieci organów administracji publicznej, [w:] Koncepcja systemu prawa administracyjnego, pod red. J. Zimmermanna, Wolters Kluwer, Warszawa 2007, s. 217-218.

${ }^{20}$ Dz.Urz. L Nr 200, s. 38.

21 Dz.Urz. L Nr 296, s. 34. 
produktów i usług w sektorze łączności elektronicznej podlegających regulacji ex ante, zwanym dalej ,zaleceniem Komisji”, Komisja Europejska stwierdzi, że proponowane rozstrzygnięcie może utrudnić rozwój jednolitego rynku lub mogłoby naruszyć prawo wspólnotowe, Prezes UKE zawiesza postępowanie na okres 2 miesięcy. W przypadku otrzymania w tym okresie wezwania Komisji Europejskiej do wycofania projektu rozstrzygnięcia, Prezes UKE uwzględnia stanowisko Komisji Europejskiej i umarza postępowanie. Ponadto Prezes UKE uwzględnia przy stosowaniu ustawy - Prawo telekomunikacyjne - w największym możliwie stopniu wytyczne Komisji Europejskiej w sprawie analizy rynku i ustalania znaczącej pozycji rynkowej oraz zalecenie Komisji w ich aktualnym brzmieniu, a w przypadku odstąpienia od ich stosowania powiadamia Komisję Europejską, uzasadniając swe stanowisko.

Współczesne prawodawstwo europejskie daje podstawy do stwierdzenia, że poziom instytucjonalizacji współpracy organów regulacyjnych między sobą oraz z organami Unii Europejskiej będzie wzrastał, aż do momentu powstania organów regulacyjnych na poziomie europejskim unijnym. Świadczy o tym w szczególności powołanie:

- Organu Europejskich Regulatorów Łączności Elektronicznej na mocy rozporządzenia Parlamentu Europejskiego i Rady (WE) NR 1211/2009 z 25 listopada 2009 r. ustanawiającego Organ Europejskich Regulatorów Łączności Elektronicznej (BEREC) oraz Urząd ${ }^{22}$;

- Agencji ds. Współpracy Organów Regulacji Energetyki na mocy rozporządzenia Parlamentu Europejskiego i Rady (WE) NR 713/2009 z 13 lipca 2009 r. ustanawiające Agencję ds. Współpracy Organów Regulacji Energetyki ${ }^{23}$.

Na mocy wskazanego rozporządzenia Parlamentu Europejskiego i Rady Organ Europejskich Regulatorów Łączności Elektronicznej (BEREC) został powołany między innymi w celu rozwijania i upowszechniania wśród krajowych organów regulacyjnych najlepszych praktyk regulacyjnych, takich jak wspólne podejścia, metodologie i wytyczne w sprawie wyrażania ram regulacyjnych UE. BEREC udziela, na wniosek, pomocy krajowym organom regulacyjnym w kwestiach regulacyjnych, Ponadto wydaje opinie w sprawie projektów decyzji, zaleceń i wytycznych Komisji w przedmiocie objętym jego właściwością. Jako cele powstania tego organu wskazuje się również sporządzanie sprawozdań i doradzanie, na uzasadniony wniosek Komisji lub z własnej inicjatywy, oraz wyda-

22 Dz.Urz. L Nr 337, s. 1.

23 Dz.Urz. L Nr 211, s. 1. 
wanie opinie dla Parlamentu Europejskiego i Rady, na uzasadniony wniosek lub z własnej inicjatywy, we wszelkich kwestiach dotyczących łączności elektronicznej należących do zakresu jego kompetencji. I wreszcie BEREC wspiera, na wniosek, Parlament Europejski, Radę i Komisję oraz krajowe organy regulacyjne w stosunkach, dyskusjach i wymianie ze stronami trzecimi; wspiera Komisję oraz krajowe organy regulacyjne $\mathrm{w}$ upowszechnianiu najlepszych rozwiązań regulacyjnych wśród stron trzecich. Struktura BEREC obejmuje Radę Organów Regulacyjnych, Urząd, w którego skład wchodzą komitet zarządzający oraz dyrektor zarządzającego. Na szczególną uwagę zasługuje Rada Organów Regulacyjnych, która składa się z jednego przedstawiciela z każdego państwa członkowskiego, będącego Zwierzchnikiem lub wyższym rangą mianowanym przedstawicielem krajowego organu regulacyjnego utworzonego w każdym państwie członkowskim, odpowiedzialnym przede wszystkim za nadzór nad bieżącym funkcjonowaniem rynków sieci i usług łączności elektronicznej.

Podobnie uregulowana została w powołanym wcześniej rozporządzeniu kwestia Agencji ds. Współpracy Organów Regulacji Energetyki. Jako jej cel podstawowy wskazuje się wspieranie organów regulacyjnych w wykonywaniu na poziomie wspólnotowym zadań regulacyjnych, które wykonują one w państwach członkowskich oraz koordynacja, w razie potrzeby, działań tych organów. W skład Agencji wchodzą rada administracyjna, rada organów regulacyjnych, dyrektor i komisja odwoławcza. Również i w tym przypadku w skład rady organów regulacyjnych wchodzą przedstawiciele organów regulacyjnych państw członkowskich, a dodatkowo - bez prawa głosu - przedstawiciel Komisji. Wśród zadań Agencji na uwagę zasługują przede wszystkim zadania wykonywane w odniesieniu do krajowych organów regulacyjnych, a w szczególności przyjmowanie indywidualnych decyzji w kwestiach technicznych, wydawanie zaleceń w celu wspierania organów regulacyjnych i uczestników rynku w dzieleniu się dobrymi praktykami, zapewnianie ram dla współpracy krajowych organów regulacyjnych, wspieranie współpracy pomiędzy krajowymi organami regulacyjnymi oraz między organami regulacyjnymi na poziomie regionalnym i wspólnotowym, przedstawianie opinii w sprawach zgodności decyzji podjętych przez organ regulacyjny z wytycznymi wynikającymi z właściwych dyrektyw i rozporządzeń.

Podsumowując ustrojowe ujęcie organów i funkcji regulacyjnyc, należy jednoznacznie stwierdzić, że organy regulacyjne stanowią w polskich warunkach nową grupę organów administracji publicznej o cechach, których nie można przypisać innym centralnym organom administracji państwowej czy rządowej, choć niewątpliwie się z tej grupy wywodzą. 
Są organami ściśle związanymi z regulacjami Unii Europejskiej, co w szczególności przejawia się w aktach normatywnych determinujących ich utworzenie oraz zadania i odpowiadające im kompetencje służące realizacji funkcji regulacyjnej.

Organy regulacyjne są ściśle powiązane z administracją europejską, a w szczególności z Komisją, jak też w zakresie realizacji prawa Unii Europejskiej stanowią jej aparat wykonawczy.

Krajowe organy regulacyjne są ponadto silnie powiązane ze swoimi odpowiednikami w innych państwach członkowskich, coraz częściej ich współpraca przyjmuje postać zinstytucjonalizowaną.

Wydaje się więc, że oddziaływanie krajowego porządku prawnego na pozycję prawnoustrojową organów regulacyjnych ulega ograniczeniu. Pozostają oczywiście sfery, które w ewidentny sposób świadczą o regulacji ich statusu przepisami prawa polskiego. Ważnym przykładem może być tutaj brak ich uprawnień do stanowienia przepisów prawa powszechnie obowiązującego jako formy działania administracji publicznej w zakresie realizacji funkcji regulacyjnej. Uprawnienia prawotwórcze organów regulacyjnych nawiązują przecież do amerykańskich pierwowzorów wykorzystanych częściowo w Europie.

\section{Summary \\ REGULATORY AUTHORITIES AND THEIR FUNCTIONS: IMPLICATIONS FOR THE RELATIONSHIP BETWEEN THE EUROPEAN AND DOMESTIC LEGAL SYSTEMS}

Poland's membership in the European Union significantly affects how public administration operates and how it interacts with the administrative authorities of the Member States, as well as with the EU institutions. While this paper does not aim at examining substantive or procedural aspects concerning regulatory authorities, in particular their specific powers or proceedings before those bodies, the aim of this paper is to present the place of regulatory bodies in the constitutional system and their role in the economy from the perspective of EU law and the Polish legal system.

Tłumaczenie: K. Jachimowicz

Keywords: public administration; regulatory authorities; regulatory bodies in the constitutional system. 


\title{
Riassunto
}

\section{L'ESERCIZIO DELLE FUNZIONI DI REGOLAZIONE DA PARTE DELLE PUBBLICHE AMMINISTRAZIONI E IL LORO IMPATTO SUI RAPPORTI TRA L'ORDINAMENTO EUROPEO E GLI ORDINAMENTI GIURIDICI NAZIONALI}

\begin{abstract}
L'appartenenza della Polonia all'Unione europea ha un impatto significativo sul sistema istituzionale polacco e il funzionamento dell'intera pubblica amministrazione. Questo impatto riguarda anche la sua interazione con le autorità amministrative degli Stati membri, nonché con le istituzioni dell'Ue. Lo scopo di questo intervento è quello di collocare le autorità amministrative indipendenti nell'ordinamento costituzionale e determinare la natura delle funzioni di regolamentazione svolte della pubblica amministrazione, nonché il loro impatto sull'economia dal punto di vista del diritto dell'Ue e il sistema giuridico polacco. Non si affrontano le questioni sostanziali e processuali, in particolare i poteri delle autorità amministrative indipendenti o il procedimento davanti a tali organi.
\end{abstract}

Tłumaczenie: K. Jachimowicz

Parola chiave: pubblica amministrazione; funzioni di regolazione da parte delle pubbliche amministrazioni; autorità amministrative indipendenti nell'ordinamento costituzionale. 
